\title{
THE IMPACT OF EVENTS AROUND OPENING OF ASIAN GAMES 2018 ON MARKET REACTIONS OF GOOD INDUSTRY CONSUMER SECTORS IN INDONESIA STOCK EXCHANGE
}

\author{
Irmayani Ni Wayan Dian*, Purbawangsa Ida Bagus Anom \\ Postgraduate Program, University of Udayana, Bali, Indonesia \\ *E-mail: dianirmayani51@gmail.com
}

\begin{abstract}
This study aims to determine the significant abnormal returns before and after the opening of the 2018 Asian Games in the stock of the Consumer Good Industry sector on the Indonesia Stock Exchange. The population in this study is the Good Industry Consumer sub-sector company on the Indonesia Stock Exchange. Determination of the sample using nonprobability method with purposive sampling technique and obtained as many as 29 companies as samples in this study. Data were analyzed using one sample t-test and paired sample t-test. The results showed that there was a market reaction at $\mathrm{t}-4$ and $\mathrm{t}-5$, but it was suspected that there was information leakage indicated by the significance value at $t-4$ and $t-$ 5 . The results of this study also indicate that there are significant differences before and after the opening of the 2018 Asian Games.
\end{abstract}

\section{KEY WORDS}

Abnormal returns, event studies, market efficiency, capital markets.

The main goal of investors in investing is to maximize returns, without forgetting the investment risk factors that must be achieved. Return is one of the factors that motivate investors to invest and also is the courage of investors to bear the risk of investments made. In essence, investors in investing will try to invest in the company's shares that are able to provide returns or profits that can be in the form of dividends and / or capital gains. Return is the main goal of an investor to invest because this is a maximization of prosperity with an increase in wealth.

Stock returns can be influenced by many things, one of which is an economic event. An economic event has an impact on investment both directly and indirectly. If an event results in an increase in stock returns, then the event is responded positively by economic actors or market players. Conversely, an event becomes ineffective if the event is responded negatively by the investor.

Research on market reactions is closely related to Market Efficiency. How a market reacts to information to achieve a new equilibrium price is important. If the market reacts quickly and accurately to achieve a new balance that fully reflects the information available, then such market conditions are called efficient markets (Jogiyanto, 2016). The relationship between market theory that explains the state of equilibrium with an efficient market concept that tries to explain how the market processes information to get to a new equilibrium position. Pangujian's impact on the 2018 Asian Games event on the Consumer Good Industry sector shares in the Indonesia Stock Exchange is an event study. Jogiyanto (2016) states that event studies (event study) are studies that study the market reaction to an event (event) whose information is published as an announcement. An event study can be used to test information content from an announcement.

Pangujian information content must be done to be able to see the reaction of an announcement. If the announcement contains information, it is expected that the market will react when the announcement is received by the market. Market reactions can be seen from changes in prices of the securities concerned. This reaction can be tested using abnormal return. Announcements are said to contain information content if one or several market participants can enjoy high abnormal returns or low returns from actual returns for a considerable period of time (Jogiyanto, 2016). 
Abnormal return is the difference between actual return and expected return. The test will involve an estimation period which is generally the period before the event. The period of events is also called the observation period or event period. In this study, the event period used was 106 days, namely on February 23, 2018 to August 9, 2018.

This study uses the Consumer Good Industry sub-sector as a sample. The choice of research location is because the researchers see the contribution of the food and beverage industry to the economy is quite large, in addition to the phenomenon described, one reason behind this research is the existence of research research gaps that have examined market reactions due to the occurrence of sports competitions among other countries. Scholtens research (2007), Mirman and Sharma (2008), Palomino (2008), Dick and Wang (2008), Harahap (2010), Berument, (2012), Ehrman (2012), Bell (2010) and Jorgensen (2012) get the result that there is a significant abnormal return in the period after the event of the competition is examined. Different results were found in the study of Matheson (2006), Martins and Serra (2007), Obi et al (2009), Darne (2016) found that there were no significant abnormal returns in the period after the events of sports competitions between other countries.

\section{LITERATURE REVIEW}

Investment is a commitment to a number of funds or other resources carried out at this time, with the aim of obtaining a number of future benefits (Tandelilin, 2010: 2). Sunariyah (2013: 15) associates investment with investment for one or more assets that are owned and usually have a long period of time in the hope of obtaining future profits. Efficient investment in production can be in the form of real assets (such as houses, land, and gold) or in the form of financial assets (securities) that are traded between investors (investors).

Investment in the form of financial assets can be in the form of direct investment and indirect investment. Direct investment is done by buying direct financial assets from a company either through intermediaries or in other ways while indirect investment is done by buying shares from investment companies that have financial asset portfolios from other companies.

A good capital market is an efficient capital market. In general, market efficiency is defined as the relationship between securities prices and information (Jogiyanto, 2016). Fama (1970) states that a market is said to be efficient if no one, both individual investors and institutional investors, will be able to obtain abnormal returns, after adjusting for risk, and by using existing trading strategies. An efficient market is a market whose securities prices reflect all information that is available and owned quickly and accurately (Jogiyanto, 2016).

Jogiyanto (2016) also defines that an efficient market if market conditions react quickly and accurately to achieve a new equilibrium price that fully reflects the information available. The faster the new information is reflected in the more efficient securities prices of the capital market, making it difficult and even impossible for investors to obtain a constant above normal level of income, namely the level of realized income higher than the expected level of income by carrying out trading transactions in the capital market.

The idea of efficient market efficiency testing is outlined in a hypothesis called the efficient market hypothesis (HPE) or efficient market hypothesis $(\mathrm{EMH})$. To find out the truth of this hypothesis, it is necessary to do empirical testing for each form of market efficiency. Fama (1970) divided market efficiency into three categories, namely:

- Testing of weak form market efficiency or tests on Return estimation (test for return predictability);

- Tests for market efficiency in half-strong forms or event studies (event studies);

- Tests of strong market efficiency or testing of private information (test for private information).

Event Study is an observation of the movement of shares in the capital market to find out whether there are abnormal returns obtained by shareholders as a result of a particular event (Peterson, 1989). Jogiyanto (2016: 643) says the event (event) in question is an event whose information is published as an announcement. The event study can be used to 
measure the information content of an announcement and can also be used to test the market for a half-strong form.

Jogiyanto (2016: 606) also said that testing information content and testing the market efficiency of a half-strong form are two different tests. Testing information content is intended to see the reaction of an announcement. If the announcement contains information, then the market is expected to react when the announcement is received by the market. This market reaction can be measured by using a return as a value of price changes or by using abnormal returns. If using abnormal returns, it can be said that an announcement containing information content will give an abnormal return to the market. Conversely, if it does not contain information, it will not give an abnormal return to the market.

The stock market does not always promise a definite return for investors, but several components of stock returns that allow investors to make profits are dividends, bonus shares and capital gains. Tandelilin (2010: 102) states that the return component consists of two types, namely yield (current income) and capital gain (profit price difference). Current income is profits obtained through periodic payments such as payment of deposit interest, bond interest, dividends and so on. Current income means that the profits received are usually in the form of cash or cash equivalents, so that they can be cashed quickly, for example a bond interest coupon m paying interest in the form of demand deposits / checks, which are only cashed, as well as share dividends, which are paid in the form of shares, which are converted into cash by selling shares received (Ang, 2010: 10).

The second component of return is capital gain, which is the profit received because of the difference in selling price with the purchase price of the investment instrument. Of course not all investment instruments are able to provide a return component in the form of capital gains. Capital gain depends on the market price of the investment instrument in question, which means that the investment instrument is traded on the market. With the trade there will be changes in investment value. Investments that provide capital gains such as bonds and stocks, while those that do not provide components of return capital gains such as certificates of deposit, savings and so on.

Actual return or return is a return that has occurred which is calculated based on historical data (Jogiyanto, 2016: 206). Actual return is important because it is used as one measure of the performance of the company. This return realization is also useful as a basis for determining the expected return. Actual return is calculated by total return by using capital gain (loss). Capital gain or capital loss is the difference from the current investment price relative to the price of the past period, if the current investment price is higher than the investment price of the previous period, capital gains occur, but if the investment price is now lower than the investment price of the past period then there is a capital loss.

Research Hypothesis. The market reaction can be shown by changes in stock prices that can be measured using abnormal returns. Announcements that have information content will give abnormal returns (Jogiyanto, 2016: 392). Abnormal return is the excess of the actual return that occurs to the normal return which is the expected return of the investor (expected return). Abnormal return is the difference between the actual return that occurs with the expected return. Return realization or actual return is a return that occurs at time which is the difference in current prices with the previous price and divided by the previous price, while the expected return is a return that must be estimated (Jogiyanto, 2016: 609). The opening of the Asian Games as an event is thought to have information content that can influence market reactions. Announcements that have information content will give abnormal returns to the market, whereas the Asian Games that do not contain information do not give abnormal returns to the market. The above statement in accordance with Lozano's (2009) research states that during the FIFA World Cup live broadcast there was a difference in activity by market players in the United States capital market compared to the usual years. Other results are also in line with research conducted by Palomino and Renneboog (2005) on 12 football teams listing on the London Stock Exchange found that soccer matches affect stock return movements.

$\mathrm{H} 1$ : There is a significant abnormal return before and after the opening of the 2018 Asian Games. 


\section{METHODS OF RESEARCH}

This study uses a comparative approach to test hypotheses regarding the differences in abnormal returns before and after events around the opening of the 2018 Asian Games on August 18, 2018.

The time period of the study used is 121 exchange days divided into two periods, namely the estimation period and the window period. The estimation period is 100 days, i.e from $t-111$ to $t-10$ before the day event. The window period is 21 days which consists of 10 days before the event (t-10), the day of the event (t0) and 10 days after the event $(t+10)$. Then the research period is from August 3, 2018 to September 4, 2018.

The reason for taking the 21-day event period is to see in detail whether there is a significant difference between the market reaction before and after the opening of the 2018 Asian Games, and to find out whether the opening of the 2018 Asian Games event affects market reactions in making investment decisions by investors or not.

\section{RESULTS AND DISCUSSION}

The basis of decision making on hypothesis making is done by comparing the calculated value with the t-table value to see events having a significant impact on the Indonesian capital market, in testing the level of significance of abnormal returns used $5 \%$. The value of $t$ table is obtained \pm 2.0481 .

Table 1 - Abnormal Return

\begin{tabular}{|c|c|c|c|c|}
\hline Period & AAR & t value & T table & Description \\
\hline-10 & 0.00581 & 0.710 & $\pm 2,0481$ & Not sig. \\
\hline-9 & 0.00199 & 0.489 & $\pm 2,0481$ & Not sig. \\
\hline-8 & 0.00364 & 0.934 & $\pm 2,0481$ & Not sig. \\
\hline-7 & 0.00054 & 0.135 & $\pm 2,0481$ & Sot sig. \\
\hline-6 & -0.0002 & -0.062 & $\pm 2,0481$ & Sig. \\
\hline-5 & 0.01257 & 2.404 & $\pm 2,0481$ & Not sig. \\
\hline-4 & 0.00989 & 2.230 & $\pm 2,0481$ & Not sig. \\
\hline-3 & 0.00144 & 0.317 & $\pm 2,0481$ & Not sig. \\
\hline-2 & -0.0006 & -0.134 & $\pm 2,0481$ & Not sig. \\
\hline-1 & -0.0022 & -0.147 & $\pm 2,0481$ & Not sig. \\
\hline 0 & 0.00292 & 0.579 & $\pm 2,0481$ & Not sig. \\
\hline 1 & 0.00653 & 1.798 & $\pm 2,0481$ & Not sig. \\
\hline 2 & 0.00245 & 0.813 & $\pm 2,0481$ & Not sig. \\
\hline 3 & 0.00581 & 1.424 & $\pm 2,0481$ & Not sig. \\
\hline 4 & 0.0017 & 0.436 & $\pm 2,0481$ & Not sig. \\
\hline 5 & -0.0073 & -1.225 & $\pm 2,0481$ & Not sig. \\
\hline 6 & 0.18698 & 0.967 & $\pm 2,0481$ & $\pm 2,0481$ \\
\hline
\end{tabular}

Source: Primary Data, 2018.

Table 1 shows the results of the average abnormal return for 29 sample companies and $t$ ( $t$-value) tests in the days of events. Positive AAR in the event period only occurs 10 days before the event and 10 days after the event.

Significant reaction on the day before the opening of ASIAN Games namely $t-4$ and $t-5$ due to information leakage and used by market participants to obtain abnormal returns. This is evidenced by the highest abnormal return value at $t-4$ and $t-5$. Information leaks that occur before the event are caused by market participants or investors knowing in advance the company's activities in the future. A significant market reaction also indicates that the market is reacting to the events of the opening of the 2018 ASIAN Games. Positive reactions caused investors to make transactions and cause stock prices to rise. 
Different test (t-test) is used to test the difference in average abnormal return before and after the opening of the 2018 Asian Games.

Table 2 - T-Test Of Average Abnormal Return After and Before Event

\begin{tabular}{ccccc}
\hline & & $\mathrm{N}$ & Correlation & Sig. \\
\hline Pair 1 & AARsebelum \& AARsesudah & 10 & .668 & .035 \\
\hline
\end{tabular}

Source: Primary Data, 2018.

Based on the results of processing data using SPSS 21.0 in table 5.4, it is known that Sig. is 0.035 , which means that $0.035<0.05$, then $\mathrm{H} 1$ is accepted and $\mathrm{H} 0$ is rejected, there is a significant difference in average abnormal return before and after the opening of the 2018 Asian Games against the shares of the Consumer Good Industry sector on the Indonesia Stock Exchange.

Average Abnormal Return Significant Before and After Around the Opening of the 2018 Asian Games. A significant average abnormal return in the events around the opening of the 2018 Asian Games against the Indonesian capital market occurred at $t-5$ and $t-4$. The results of this study indicate that there is information content on the events around the opening of the 2018 Asian Games against the reaction of the capital market in Indonesia so that hypothesis $1(\mathrm{H} 1)$ is accepted. At $t-10$ to $t-9$ statistically it shows insignificant results. The results of the study can be interpreted that the capital market players on $\mathrm{t}-10$ to $\mathrm{t}-9$ events prefer to take action before selling or buying. At $t-8$ to $t-6$ statistically it shows insignificant results. The results of the study can be interpreted that the capital market players on $\mathrm{t}-8 \mathrm{to} \mathrm{t}-$ 6 events prefer to take action to wait before selling or buying. The average abnormal return value at $\mathrm{t}-5$ to $\mathrm{t}-4$ shows significant results. The results of the study can be interpreted that before the opening of the 2018 Asian Games event, the capital market players assumed that the information could provide benefits for the issuers of the Good Consumer Industry sector in Indonesia, then they took action so that the stock price rose. A significant market reaction also indicates that the market is reacting to events.

The average abnormal return value at $\mathrm{t}-3$ shows insignificant results. The results of the study can be interpreted that after buying the previous day, the capital market players assumed that the stock price had risen too high, then they had to sell, causing the stock price to fall. The average abnormal return value at $t-2$ to $t-1$ shows the results of -0.0006 and 0.0002 . The results of the study can be interpreted that information on the opening of the 2018 Asian Games has leaked and capital market players think that information has a negative impact, then they prefer to sell off, causing the stock price to fall. At $t+1$ to $t+4$ statistically it shows insignificant results. The results of the study can be interpreted that the capital market players at $t+1$ to $t+4$ events prefer to take action before selling or buying. The average abnormal return value at $t+5$ shows the results of -0.0073 . The results of the study can be interpreted that information on the opening of the 2018 Asian Games has leaked and capital market players think that information has a negative impact, then they prefer to sell, causing stock prices to fall. At $t+6$ to $t+10$ the results are not significant. The results of the study can be interpreted that the capital market players at $t+6$ to $t+10$ events prefer to take action before selling or buying.

The results of this study support the semi-strong form of efficient market theory where, there are abnormal returns obtained by capital market players around the occurrence of an event. The results of this study are in line with the research conducted by Palomino (2008) proving that the victory of the football team listing on the London Stock Exchange has a significant effect on the value of abnormal stock returns.

The impact of the opening of the 2018 Asian Games on the reaction of the Indonesian capital market as indicated by the abnormal return value states that there are significant differences in average abnormal returns before and after the opening of the 2018 Asian Games. This is indicated by a significance value smaller than 0.05 and $t$-value accepts $\mathrm{H} 1$. 
The significant difference in average abnormal return before and after the opening of the 2018 Asian Games indicates that investors are interested in investing throughout the period.

Positive reactions caused investors to make transactions and cause stock prices, especially in the Consumer Good Industry Sector to increase. This positive reaction can also be caused by investors trusting the company's prospects in the future. The results of this study are in line with the research conducted by Pratiwi and Ahmar (2016). The results of different tests on Singapore and Thailand countries can be obtained Singapore $p$-value value of 0,000 and Thailand at 0,001 , the $p$-value of the two countries is smaller than significance of 0.05 then $\mathrm{Ho}$ is rejected, this means that the average return generated is significantly different during the observation period, namely before, during and after the world cup in 2014. The results of this study are in line with the research conducted by Dohmen (2006) which found that the soccer team match in the FIFA World Cup 2006 could have an impact on the economic outlook and fluctuations in stock prices in Germany. This result is also in line with research conducted by Lozano (2009) revealing that during the FIFA World Cup live broadcast there was a difference in activity by market participants in the United States capital market compared to the usual years.

The results of this study are in line with Kaplanski (2013) which proves that noneconomic factors such as sports have a significant effect on stock returns and risk expectations in the Dutch capital market.

\section{CONCLUSION}

The results of testing the data using a different test (t-test) average abnormal return before and after the opening of the 2018 Asian Games show that there are statistically significant abnormal return differences before and after the opening of the 2018 Asian Games event. The test results also show that during the period Estimates have a consistent positive average abnormal return, this means that investors get a realization return that is greater than the expected return. The market has begun to react on $\mathrm{H}-5$ and $\mathrm{H}-4$ by showing the difference in abnormal returns with the day of the event.

\section{SUGGESTIONS}

For stock investors in the Indonesia Stock Exchange (IDX) who have information about the events of the opening of the 2018 ASIAN Games so that in the future they can always make selling and buying decisions on stocks that have an impact on the Asian Games event. Research sites that are only examined in the Consumer Good Industry sector of the Indonesia Stock Exchange alone and focus on abnormal returns only, further research is expected to be able to examine the $\mathrm{JCl}$ and observe capital markets outside Indonesia such as the Nikkei 225 Index, the Hang Seng Index, the Shanghai Composite Index, The Straits Times Index, the FTSE 100 Index, the Dow Jones Index, the S \& P 500 Index or the Nasdaq to see whether the foreign capital market has the same impact on Indonesia.

Research Limitations:

- Research locations that are only examined in the Consumer Good Industry sector of the Indonesia Stock Exchange only and focus on abnormal returns;

- Calculation of abnormal returns in the event period using the market model.

\section{REFERENCES}

1. Amélie Charles, Olivier Darné. Stock market reactions to FIFA World Cup announcements: An event study. Economics Bulletin, Economics Bulletin, 2016, 36 (4), pp.2028-2036.

2. Bell, Adrian. 2010. Over the Mean or Sick as a Parrot? The Effects of Football Results on a Clubs Share Price. Journal of Applied Economic.

3. Berument, M.H and Nildag B. 2012. The Social Science Journal 49, 368-374. 
4. Ehrman, M and David J. 2012. Investor Inattention During FIFA World Cup Matches. Working Paper Series No 1424.

5. Harahap, ID. 2010. Analisis FIFA World Cup Effect terhadap Return and Volatilitas IHSG di BEl Periode 1994, 1998, 2002, 2006 and 2010. Jakarta: Program Pascasarjana Universitas Indonesia.

6. Jogiyanto, Hartono. 2016. Teori Portofolio and Analisis Investasi. Edisi ke 11. Yogyakarta: BPFE.

7. Jorgensen, et al. 2012. The News Model of Asset Price Determination An Empirical Examination of The Danish Fotball Club. Discussion Paper No. 313. ISSN 1860092.

8. Kaplanski, Guy, et all. 2013. Do Happy People Make Optimistic Investors?.Journal of Financial and Quantitative Analysis.

9. Lozano, Fernando. 2009. The Flexibility of the Workweek in the United States (AS) Evidence From the FIFA World Cup. IZA Discussion Paper No 4217.

10. Matheson. V.A. (2006). Mega-events: the effect of the world's biggest sporting events on local, regional, and national economies. College of the Holy Cross.

11. Martins, A.M., and A.P. Serra, 2007, Market impact of international sporting and cultural events, Working Papers 0720, International Association of Sports Economists.

12. Mirman, M., and R. Sharma, 2008, Stock market reaction to Olympic Games announcement, Applied Economics Letters 99999, pp. 1-4.

13. Nanda, Ramaditya Dwi. 2015. Reaksi Pasar Modal Indonesia Terhadap Kebijakan Tax Amnesty Indonesia pada Saham LQ45 Tahun 2016-2017. Jurnal Administrasi Bisnis Universitas Diponogoro. 1-13.

14. Obi, P., Surujlal, J. and O. Okubena (2009) "South African equity market reaction to the 2010 World Cup announcement" African Journal for Physical Health Education, Recreation and Dance 9, 284-296.

15. Pratiwi and Ahmar. 2016. World Cup 2014 and Return Saham Perusahaan Pada Pasar Modal ASIAN.Jurnal Politeknik Negeri Jakarta, Vol.6,pp . 470-475.

16. Pratiwi Ratih, Muhammad Yusuf. 2015.Reaksi Pasar Dalam Bentuk Return Sebelum, Selama, and Sesudah Peristiwa Piala Dunia Tahun 2014 pada Pasar Modal Asian. Jurnal Riset Akuntansi and Perpajakan JRAP Vol. 2, No. pp. 229 - 237.

17. Scholtens, B and Witje, P. Scoring on the Stock Exchange? The Effect of Football Matches on Stock Market Return: on Event Study. 2007. Journal Applied Economics.

18. Peša, A. R., and Brajković, A. 2016. Testing The 'Black Swan Effect'on Croatian Stock Market Between 2000 and 2013.Emerging Markets Journal, Vol.6, No.1, pp. 1-16.

19. Pratama, I G B. 2015. Reaksi Pasar Modal Indonesia Terhadap Peristiwa Politik. Ejournal S1 Ak Universitas Pendidikan Ganesha, Vol. 3, No.1, pp. 1-11.

20. Purba, F., and Handayani, S. R. 2017. Analisis Perbedaan Reaksi Pasar Modal Indonesia Sebelum and Sesudah Peristiwa Non Ekonomi. Jurnal Administrasi Bisnis, Vol. 51, No.1, pp. 115-123.

21. Purba, S., and Silalahi, M. 2017. Dampak Quick Count Pilpres 2014 terhadap Harga Kurs Usd, Abnormal Return and Aktivitas Volume Perdagangan Saham di BEl. Jurnal IImiah Methonomi, Vol. 3, No. 1, pp. 134-142.

22. Rahmawati, I. Y., and Pandansari, T. 2016. Reaksi Pasar Modal dari Dampak Peristiwa Bom Plaza Sarinah Terhadap Abnormal Return Perusahaan Lq 45 yang Terdaftar di BEl. Riset Akuntansi and Keuangan Indonesia, Vol.1, No.2, pp. 126-133.

23. Ramesh, S and S. Rajumesh. 2015. Stock Market Reaction to Political Events: A Study of Listed Companies in Colombo Stock Exchange of Sri Lanka. Journal of Economics and Sustainable Development, Vol.6, No.3, pp. 131-139.

24. Rundengan, J. M., Mangantar, M., and Maramis, J. B. 2017. Reaksi Pasar Atas Pelantikan Sri Mulyani Sebagai Menteri Keuangan Pada 27 Juli 2016. Jurnal Riset Ekonomi, Manajemen, Bisnis and Akuntansi, Vol.5, No.3, pp. 2731-2741.

25. Scholtens, B and Witje, P. 2007. Scoring on the Stock Exchange? The Effect of Football Matches on Stock Market Return: on Event Study. Journal Applied Economics.

26. Tandelilin, Eduardus. 2010. Portofolio and Investasi. Edisi Pertama. Yogyakarta: Kanisius Najaf. 